\title{
Cenas cariocas: a teatralidade dos espaços em três contos de Machado de Assis
}

\author{
Claudia Barbieri Masseran*
}

\begin{abstract}
Resumo
A cidade do Rio de Janeiro apresenta-se como uma das principais personagens machadianas. $\mathrm{O}$ escritor perscrutou os bairros, os largos, as praças, as ruas, avidamente. Dedicou a ela tantas páginas, com tão variadas feições, que a cidade multiplicou-se literariamente. Entre os muitos recursos estilísticos empregados por Machado de Assis (1839-1908) na constituição dos seus espaços narrativos, sejam eles urbanos ou não, destaca-se, sobretudo, o uso recorrente da composição cênica. Marcações e fragmentações de cena, dramaticidade textual, cortes narrativos são alguns dos elementos que corroboram a construção teatral dos espaços. Para o entendimento da teatralidade presente nesse processo compositivo, o trabalho elege três contos pertencentes ao volume Várias Histórias, publicado em 1896, como corpus de análise: "A cartomante", "O diplomático" e "Mariana".

Palavras-chave: Literatura e cidade. Espaço narrativo. Representações urbanas. Machado de Assis.
\end{abstract}

\section{Scènes Cariocas: la théâtralité des espaces dans trois nouvelles de Machado de Assis}

\begin{abstract}
Resumé
La ville de Rio de Janeiro se présente comme l'un des principaux personnages machadiens. Il parcourait avec avidité les quartiers, les rues, les places, les rues. Il y consacrait tant de pages, avec tant de traits, que la ville se multipliait littéralement. Parmi les nombreuses caractéristiques stylistiques employées par Machado de Assis (1839-1908) dans la constitution de ses espaces narratifs, qu'ils soient urbains ou non, l'utilisation récurrente de la composition scénique se distingue. Marquages et fragmentations de scène, drame textuel, coupures narratives sont quelquesuns des éléments qui corroborent la construction théâtrale des espaces. Pour la compréhension de la théâtralité présente dans ce processus de composition, l'œuvre sélectionne trois histoires courtes appartenant au volume Various Histories, publié en 1896, comme corpus d'analyse: "La diseuse de bonne aventure", "Le diplomate" et "Mariana".

Mots-clés: Littérature et ville. Espace narratif. Représentations urbaines. Machado de Assis.
\end{abstract}

Recebido: 28/03/2018

Aceito: $07 / 11 / 2018$

\footnotetext{
* Universidade Federal Rural do Rio de Janeiro (UFRRJ). Doutora e Professora adjunta de Literatura Portuguesa no Instituto de Ciências Humanas e Sociais (ICHS), junto ao Departamento de Letras e Comunicação (DLC) da Universidade Federal Rural do Rio de Janeiro (UFRRJ).
} 


\section{Introdução}

Iniciar a leitura de algum romance ou conto machadiano implica aceitar o convite, legado pelo escritor, de adentrar na intimidade da existência humana. Uma busca sôfrega pela compreensão dos sentimentos, das atitudes, das relações sociais, do seu tempo, do seu meio. Ao versar sobre temas tão universais o escritor poderia, facilmente, ter caído no ardil da superficialidade. Não Machado de Assis. O criador dos "olhos de ressaca" soube escrever sobre o homem e tudo aquilo que lhe era inerente, de forma intensa, porém delicada. Soube ser contestador sem transformar-se num leviano. Trouxe o caráter público para dentro da residência de suas personagens, conferindo-lhes um trato próximo, quase doméstico. Tal cuidado estendeu também aos seus leitores. Ao dialogar diretamente conosco, nos transformou em seus confidentes. Fomos ouvintes curiosos, gratos pela partilha de tantas histórias.

Talvez não seja escusado dizer que este sopro de intimidade - brisa fresca que permeia a escrita machadiana - seja, enfim, um dos traços diferenciadores e mais característicos de sua estética.

A composição do espaço narrativo não ficou imune a tal aragem. Ambientes públicos e privados, ruas, praças, paisagens, quartos e salas são estruturados com pouquíssimos elementos. Este comedimento no uso das palavras não acarreta prejuízo algum de compreensão por parte do leitor. Ao contrário, - a precisão das informações passadas garante completo entendimento e permite, por meio da leitura, uma liberdade criativa na construção imagética dos espaços.

Este tipo de estruturação, cuja formação fica atrelada à disposição de elementos pontuais, aproximase muito do arcabouço dramático, ou, em outras palavras, do texto de teatro. O enredo constrói-se pelo encadeamento de unidades narrativas fragmentadas, pequenas cenas costuradas e tramadas pela pena do artista. A paixão pelo teatro, nutrida por Machado desde a infância, influenciou sobremaneira sua escrita, transparecendo em seus romances, contos e suas crônicas, numa espécie de linguagem cênica, resultado do diálogo entre o texto dramático e o narrativo.

Todo este universo literário deambula por um palco específico: a cidade do Rio de Janeiro, durante a vigência do Segundo Reinado até as primeiras décadas da República. Machado de Assis, na construção das suas narrativas breves, explora os espaços mais privativos deste contexto urbano, dotando a atmosfera doméstica de influências socioculturais cosmopolitas, por meio dos hábitos e costumes desenvolvidos pela sociedade. Os dramas desenrolam-se, portanto, entre as paredes dos salões burgueses e a cidade, com seus vícios e virtudes, adentra as residências pelas janelas abertas, pelos convidados e visitas que transpõem os umbrais das portas. Os elementos espaciais, como mencionado anteriormente, são poucos e precisos e funcionam como as rubricas nos textos teatrais: pontuam a informação, sendo suficientes e essenciais para a construção cênica.

Assim, este artigo pretende aproximar o texto machadiano do texto dramático, observando como a construção do espaço narrativo e do desenvolvimento do enredo se apropriam dos elementos teatrais para a sua constituição. Pretende ainda observar como a cidade do Rio de Janeiro avulta nas linhas dos contos escolhidos: "A cartomante", "O diplomático" e "Mariana", integrantes do volume Várias Histórias, publicado em 1896.

\section{Rio de Janeiro oitocentista}

De pano de fundo para assunto principal, causa e consequência das ações de personagens, a cidade de São Sebastião inspirou um elevado número de obras no século XIX, de poemas a pinturas e aquarelas, de romances a peças teatrais. 
Esta consagração urbana oitocentista se deveu, sobretudo, à instalação da Corte Portuguesa, que migrava em virtude das guerras napoleônicas em 1808. A cidade passava de um território de colônia ao status de metrópole, enquanto capital do império. É oportuno recordar o impacto que tal mudança operou: no final do século XVIII a cidade não totalizava 45 mil habitantes. Apenas a comitiva que acompanhava a corte ultrapassava 20.000 pessoas e o Rio chegaria ao final do século, com mais de 500 mil habitantes. ${ }^{1}$

Período rico em mudanças políticas durante as quais o Rio estetizou sua aparência por meio do trabalho contínuo empreendido por sucessivas ações urbanísticas, que buscavam dotar ruas e praças, bem como seus principais monumentos, de aspectos europeus. Neste sentido, Paris se configurava como a principal referência citadina, modelo urbano por excelência, principalmente após as reformas empreendidas pelo Barão Haussmann, durante o Segundo Império. Os passeios arborizados, os cafés e os teatros, os bulevares com suas esplanadas, os longos eixos que enquadravam os monumentos imponentes tornaram-se, paulatinamente, o cenário perfeito para o desenvolvimento do mito da cidade de Paris. A civilidade encontrara o berço no velho mundo e todos acorriam para respirar os seus ares: escritores, artistas, jornalistas, pintores, burgueses ricos, nobres.

Aos poucos, sua influência era generalizante. As cidades ao redor do mundo buscavam transformar seus traçados urbanos, extirpando quaisquer aspectos tacanhos de ruas estreitas, com características medievais. A moda chegava acomodada em caixas e descrita em revistas pelos paquetes. $\mathrm{O}$ francês tornava-se a preferida nos salões e outros locais de circulação nobre. A culinária invadia os cardápios e definia a elegância dos jantares e das recepções. A decoração das residências abundava nos tecidos de revestimento, nos bibelots, no estilo dos móveis, no uso dos reposteiros e das poltronas, na conformação dos palacetes, com seus jardins, escadas laterais e claraboias. O alcance parisiense era completo e refletia-se nos mais variados níveis e costumes sociais.

O Rio de Janeiro foi intensamente influenciado pelo imaginário urbano francês, contudo, suas transformações não se efetivaram ao longo do século XIX, mas, sim, nas primeiras décadas do século $\mathrm{XX}$, com as reformas empreendidas por Pereira Passos.

A cidade se expandiu primeiro na direção norte, denominada "Cidade Nova", e, posteriormente, na direção sul, Botafogo, Copacabana e Ipanema. Os novos bairros, que tinham como referência os subúrbios parisienses, como o caso de São Cristóvão, apresentavam construções diferentes das do Centro (Cidade Velha), com residências mais amplas. A população abastada que habitava a região central, aos poucos migrou para as partes novas e essas antigas casas, tanto as térreas, quanto as assobradadas, passaram a ser ocupadas pela população menos favorecida. Muitas residências foram subdivididas e tornaram-se habitações coletivas, como cortiços ou pequenas vilas, ou, então, foram ocupadas pelo comércio.

Em 1850 apareceram os primeiros bondes e trens, e, na mesma década, foram instalados os primeiros lampiões a gás. A eletricidade só chegaria à dita cidade trinta anos mais tarde e, em 1891, os antigos lampiões foram substituídos pelas lâmpadas. Os novos meios de transporte facilitaram o deslocamento das pessoas, corroboraram na ocupação de bairros mais afastados, permitindo, assim, que a população residisse longe de seus locais de trabalho. Mas vale lembrar que a maioria destes arruamentos não era calçada e não possuía nenhum tipo de benfeitoria urbana. Bem ilustrativa dessa situação é uma crônica de Machado, escrita em 15 de setembro de 1876, pertencente à série História de quinze dias. Nela o cronista comenta o pedido de calçamento da Rua das Laranjeiras, feito pelos moradores às autoridades competentes:

Talvez [os empresários] sejam tão exigentes como os moradores da Rua das Laranjeiras, que estão a bradar que a mandem calçar, como se não bastasse morar em rua de nome tão poético.

1 Dados extraídos do livro Europa, França e Bahia, de Eloísa Petti Pinheiro, de 2002. A referência completa encontra-se no final do artigo. 
É certo que, em dias de chuva, a rua fica pouco menos lamacenta que qualquer sítio do Paraguai. Também é verdade que duas pessoas, necessitadas de comunicar uma coisa à outra, com urgência podem vir desde o Cosme Velho até o Largo do Machado, cada uma de sua banda, sem achar lugar em que atravessem a rua.

Finalmente, não se contesta que sair do bond, em qualquer outra parte da dita rua, é empresa só comparável à passagem do mar Vermelho, que ali é escuro.

Tudo isso é verdade. Mas em compensação, que bonito nome! Laranjeiras! Faz lembrar Nápoles; tem uns ares de idílio: a sombra de Teócrito deve por força vagar naquelas imediações.

Não se pode ter tudo, - nome bonito e calçamento; dois proveitos não cabem num saco. Contentemse os moradores com o que têm, e não peçam mais, que é ambição. (ASSIS, 1997a, p.48).

Os problemas apresentados pela população são abordados, pelo escritor, humoristicamente. A graça da crônica não esconde a gravidade da situação. Assim, por características próprias da sua formação, a cidade do Rio diferia de Paris ou de outras capitais europeias. Nestas cidades, o uso do espaço público era um grande atrativo, não só pelo comércio diverso e sedutor, mas também pela presença de outros elementos paisagísticos como jardins, parques e praças e de espaços de encontros e convívio como cafeterias, confeitarias e restaurantes.

A população do Rio não dispunha de sítios assim. O comércio sedutor concentrava-se na Rua do Ouvidor e adjacências. Para Machado, o "rosto da cidade fluminense é essa rua", afinal, era "onde todos moravam em certas horas do dia". Isso se dava porque, segundo o escritor, existiam horários certos para frequentá-la. Depois do meio-dia, o movimento intensificava-se até às quatro horas, sendo "de mau gosto andar na rua do Ouvidor às 5 horas da tarde", mas quando anoitecia, voltavam os habitantes elegantes, pois era "lindíssima à noite, iluminada pela trêmula chama do lampião a gás". Os rapazes postavam-se "às portas das lojas, vendo passar as moças" e a rua pertencia, assim, “exclusivamente à fashion, à aventura e ao namoro". (ASSIS, 1997a, p. 74).

O Passeio Público, já existente em 1783, tornou-se um espaço decadente até meados de 1860 , quando foi completamente remodelado e entregue aos habitantes da capital. Havia também o Campo de Sant'Ana, um grande espaço aberto, muito utilizado para festas populares e corridas de touros, segundo relata Joaquim Manuel de Macedo no livro Um passeio pela cidade do Rio de Janeiro.

Portanto, de modo distinto de outras capitais europeias, onde a rua tornou-se lugar de encontro, de exposição pública, de diversão, de interação social e de satisfação dos desejos de consumo, no Rio, poucos eram os espaços públicos onde essas ações podiam acontecer de fato. A solução encontrada foi transferir tais atividades para os espaços privados. O salão foi, indubitavelmente, o ambiente por excelência da sociabilidade e do entretenimento da burguesia fluminense, concorrendo com os teatros, clubes musicais e cassinos.

Inúmeros são os documentos históricos, crônicas, pinturas e fotografias que registraram a vivência urbana da capital do Brasil no século XIX, que corroboram esta leitura privada da vivência social.

As ruas cariocas caracterizavam-se por uma vida intensa: gente em constante movimento, mercadorias expostas, muitos ruídos, muitas ruas estreitas ainda. Mas essa multidão era composta, sobretudo, por escravos, negros livres, trabalhadores braçais, entregadores, caixeiros, viajantes. $\mathrm{O}$ eterno vaivém, que enchia as ruas de ritmo aos gritos dos pregões, dos anúncios das mercadorias, restringia o ir e vir das jovens, das damas e das pessoas "da boa sociedade".

A cidade do Rio de Janeiro - enquanto grande personagem machadiana - foi conduzida habilmente para dentro da intimidade das residências. Festas, bailes, serões, partidas de jogos e outros costumes tipicamente cosmopolitas, desenvolviam-se em espaços restritos, privados e domésticos. Tais ambientes sediam muitos contos do escritor: propiciam a ação, motivam as personagens, albergam o desenrolar do enredo, precipitam situações. Isto não significa dizer que o escritor deixasse de explorar as ruas, paisagens e demais espaços públicos cariocas. Ao contrário, incorporou em suas narrativas os logradouros, os bairros, os teatros, o comércio, o passeio público, os jardins, largos e chafarizes. Entretanto, em suas histórias breves, Machado explorou o caráter intimista do convívio entre as 
personagens e as cenas urbanas são incidentais, constroem-se como elementos de passagem entre as unidades narrativas. Tal característica, entretanto, em nada lhes diminui o valor e importância dentro dos enredos em que se inserem. Este fator, aliás, mostra-se bem revelador do Rio de Janeiro da época.

\section{0 escritor e a cidade}

A cidade escrita, descrita, criada ou reinventada na literatura, merece algumas considerações. Um escritor que elege uma cidade como o espaço acolhedor para sua ficção depara-se, quase que no mesmo instante, com uma problemática. Se o escritor for habitante de tal cidade, naturalmente deve possuir predileção por determinados lugares, e, muito provavelmente, deve nutrir alguns sentimentos por ela, positivos ou negativos. Seria possível manter-se imparcial, na escolha das palavras, no ato da transposição literária? Seria possível, ao escritor, eximir-se completamente?

Contudo, se a cidade escolhida não fosse a mesma que o escritor habitasse, mas alguma que apenas conhecesse ou imaginasse, haveria imparcialidade nesse processo memorialista ou criativo? A escrita literária nunca é totalmente imparcial, mesmo quando vinculada ao princípio da mímese. A composição do enredo, das personagens, dos espaços, exige que o escritor, a todo instante, realize uma série de escolhas: a heroína será loira, morena ou ruiva? Possuirá cabelos volumosos e abundantes? Residirá em qual bairro da cidade? Pertencerá a qual classe social? Que cor de vestido lhe ficará melhor? Qual será a cor de seus olhos? Estes exemplos, apesar de simplórios, são pertinentes. Escrever pressupõe uma escolha de palavras (verbos, substantivos e adjetivos) que são reveladoras por si mesmas.

Não há imparcialidade na escolha. Assim, a escrita da cidade está impregnada da percepção do escritor. O romancista criou, para cada obra, uma interpretação e um juízo a respeito da cidade - uma maneira de vê-la e avaliá-la como uma série de experiências em coerência apenas com o seu ser interior e com a sua intencionalidade artística. Assim, cada obra, cada texto literário guarda em si um registro único do escritor.

A literatura é esclarecedora na medida em que testemunha como uma cidade é percebida, vivenciada e interpretada, como faz sentido para os seus habitantes ao passar dos tempos. Ela expressa a formação e a transformação da consciência e da experiência dos lugares, dotando a cidade de uma linguagem, tornando-a um espaço cuja legibilidade altera-se historicamente.

Desse modo, como arranjar histórica, espacial e criticamente as possibilidades ficcionais que a cidade oferece cotidianamente? A relação estética entre forma e matéria torna-se, portanto, um conjunto importante, quando se estuda o modo pelo qual um escritor funde sua visão social da cidade às técnicas formais que recorre para expressar adequadamente essa mesma visão. Assim, o tema, a estrutura, o enredo, as personagens, os espaços se tornam agentes empregados pelo artista para vitalizar a sua própria percepção da cidade.

Estabelecer relações entre uma cidade e um escritor exige alguns cuidados. O primeiro deles, e, talvez, o mais importante, é evitar reducionismos. É imprudente falar de uma Londres de Charles Dickens, de uma Paris de Zola ou de um Rio de Janeiro de Machado de Assis. Cada obra mostra-se como um universo novo para o escritor e, como tal, cada romance, cada conto pode expressar uma visão diferente da cidade. Não existe apenas uma Londres de Dickens, mas várias. Cada personagem pode desenvolver uma percepção individual da cidade e, nada impede, que esta percepção mude de acordo com as suas sensações e sentimentos. Homem e cidade mudam constantemente. Escreveu Machado em Notas semanais, na crônica "O ofício do cronista", de 14 de agosto de 1878: "Consolemo-nos; é isto mesmo a vida de uma cidade, ora tétrica, ora frívola, hoje lúgubre, amanhã jovial, quando não é todas as coisas juntas." (ASSIS, 1997b, p.26).

A visão expressa por um escritor em um livro de juventude pode e muito provavelmente não será a mesma em uma obra de maturidade. 


\section{Cenas cariocas}

Em 1896 veio a lume o título Várias Histórias, a quinta coleção do gênero apresentada aos leitores por Machado de Assis. Ao todo compunham o exemplar dezesseis narrativas curtas que, publicadas esparsamente nos jornais, foram reunidas em volume. Tanto o conto "A cartomante", que abre o livro, quanto "O diplomático", foram publicados na Gazeta de Notícias em 1884. Sete anos depois, em 1891, "Mariana" aparecia nas páginas da Gazeta.

Em "A cartomante", Machado cria a intertextualidade com o teatro logo nas primeiras linhas, pois principia o texto com uma referência à trágica peça Hamlet, de William Shakespeare. Esta primeira frase adquire um significado simbólico e revelador no transcorrer do enredo, além de abrir um diálogo atemporal entre o conto e a peça do século XVII:

Hamlet observa a Horácio que há mais cousas no céu e na terra do que sonha a nossa filosofia. Era a mesma explicação que dava a bela Rita ao moço Camilo, numa sexta-feira de novembro de 1869, quando este ria dela, por ter ido na véspera consultar uma cartomante; a diferença é que o fazia por outras palavras. (ASSIS, 1904, p.3).

Neste primeiro parágrafo, de forma sucinta, são apresentadas duas personagens, Rita e Camilo, além da data e de uma diferença de crenças entre ambos. A bela Rita acreditava em certo misticismo, afinal consultara uma cartomante, enquanto o moço Camilo demonstrava incredulidade ao rir de sua atitude. Poucas informações a respeito das características físicas e dos traços de personalidade serão acrescidas a estas notas dadas logo no início. De Rita saberemos ainda que era uma "dama formosa e tonta", "graciosa e viva nos gestos", que possuía "olhos cálidos, boca fina e interrogativa" e que "contava trinta anos". (ASSIS, 1904, p. 4). Camilo, mais jovem quatro anos, "era um ingênuo na vida moral e prática". Não possuía "nem experiência, nem intuição". (ASSIS, 1904, p.4). Testemunhamos este breve diálogo entre os jovens, em uma cena que guarda reminiscências passionais que o leitor surpreende como se adentrasse, de maneira quase furtiva, o espaço e surpreendesse as personagens em meio a uma conversa íntima e privada.

Rita, certa da perda da estima de Camilo, havia consultado uma cartomante para que esta pudesse lhe afiançar os sentimentos do jovem e sanar as suas dúvidas. Este, por sua vez, após restituir à moça a convicção do seu amor, sente-se lisonjeado por ser alvo de sentimento tão forte. Tranquilizados, encerram o encontro e separam-se:

A casa do encontro era na antiga Rua dos Barbonos, onde morava uma comprovinciana de Rita. Esta desceu pela Rua das Mangueiras, na direção de Botafogo, onde residia; Camilo desceu pela da Guarda Velha, olhando de passagem para a casa da cartomante. (ASSIS, 1904, p.5).

Este fragmento é bem ilustrativo do uso que o escritor faz das cenas de espaço público em seus contos. As denominações dos logradouros servem para localizar espacialmente as personagens, especificando a classe social a que pertenciam. No caso específico, tanto a Rua dos Barbonos (atual Evaristo da Veiga), bem como a Guarda Velha (atual 13 de Maio) localizam-se no centro da cidade, informação esta que não é fortuita. O casal, que havia construído um relacionamento adúltero, se encontrava, furtivamente, na casa de uma amiga de Rita, o que não levantaria suspeitas caso ela fosse vista por algum conhecido. A região central, por sua vez, justificaria, ainda, a presença de Camilo, caso este fosse confrontado por alguém. O conhecimento da trama urbana da cidade do Rio de Janeiro, pelo leitor, é quase que obrigatório para a percepção desses aparentes detalhes. O espaço define socialmente a personagem, sendo autoexplicativo quanto a alguns traços de sua personalidade.

O entrecho esclarece ainda que Rita habitava no bairro de Botafogo, zona residencial com chácaras extensas e grandes palacetes aristocráticos, informação esta que corrobora no entendimento de Rita e 
Vilela, seu marido, possuírem uma situação financeira bem estabelecida.

Após esta breve passagem, o narrador onisciente dá início a uma analepse, que procura retomar os fatos desconhecidos do leitor, explicando como os dois conheceram-se e, mais importante, como se formou o triângulo amoroso: "Vilela, Camilo e Rita, três nomes, uma aventura e nenhuma explicação das origens. Vamos a ela" (p.6).

O diálogo entre o narrador e os leitores é muito frequente no texto machadiano, que explora o formato também na conversação entre as personagens. Esta desenvoltura compositiva garante fluidez e ritmo ao texto. Ficamos sabendo, nesta breve analepse, que Camilo e Vilela eram amigos de infância, que este último ausentara-se da capital por algum tempo, regressando já casado com Rita. Os amigos se reencontraram. "Uniram-se os três. Convivência trouxe intimidade." (ASSIS, 1904, p.7). O uso das frases curtas, seguidas umas das outras, é outro recurso explorado pelo autor neste conto. Além de pontuar as ações, essas construções frasais possuem simbolicamente o aspecto conclusivo, como se uma ação decorresse naturalmente da ação anterior, constituindo, desse modo, o desenrolar esperado, inevitável das coisas. Assim, Rita e Camilo envolvem-se romanticamente, fruto da convivência diária, da partilha dos serões, dos jogos, dos passeios conjuntos.

Camilo quis sinceramente fugir, mas já não pôde. Rita, como uma serpente, foi-se acercando dele, envolveu-o todo, fez-lhe estalar os ossos num espasmo e pingou-lhe o veneno na boca. Ele ficou atordoado e subjugado. Vexame, sustos, remorsos, desejos, tudo sentiu de mistura; mas a batalha foi curta e a vitória delirante. Adeus, escrúpulos! Não tardou que o sapato se acomodasse ao pé, e aí foram ambos, estrada fora, braços dados, pisando folgadamente por cima de ervas e pedregulhos, sem padecer nada mais que algumas saudades, quando estavam ausentes um do outro. (ASSIS, 1904, p.8).

No conto fica explícito que foi o comportamento de Rita que suscitou a paixão de Camilo: seus olhos teimosos procuravam continuamente os dele, suas mãos frias, seus bilhetes distantes. A comparação com uma serpente calculista, que o envolveu ardilosamente, despertando sentimentos e sensações, até se tornar imprescindível, aproxima a personagem do arquétipo da femme fatale. O relacionamento desenvolve-se até o instante em que Camilo recebe uma carta anônima, recurso este amplamente utilizado nos melodramas e comédias do repertório francês. A necessidade de manter as aparências e de despistar quaisquer conclusões por parte de Vilela obriga o casal se ver com menor frequência. Camilo se afasta e deixa de aparecer nos serões em Botafogo.

Depois de explicados estes pormenores, o narrador retoma o enredo da história, no exato momento em que a havia interrompido. A lógica do texto, portanto, se efetiva pela enunciação do narrador, que, habilmente, compõe a sequência entre as cenas e organiza os vários fragmentos narrativos:

Foi por esse tempo que Rita, desconfiada e medrosa, correu à cartomante para consultá-la sobre a verdadeira causa do procedimento de Camilo. Vimos que a cartomante restituiu-lhe a confiança, e que o rapaz repreendeu-a por ter feito o que fez. Correram ainda algumas semanas. (ASSIS, 1904, p.9).

O comportamento de Vilela muda, torna-se sombrio e então ele escreve a Camilo o fatídico bilhete: "Vem já, já, à nossa casa; preciso falar-te sem demora." (ASSIS, 1904, p. 10). Receoso que o amigo houvesse descoberto a traição e temeroso pela situação vindoura, visualiza a tragédia:

Imaginariamente, viu a ponta da orelha de um drama, Rita subjugada e lacrimosa, Vilela indignado, pegando da pena e escrevendo o bilhete, certo de que ele acudiria, e esperando-o para matá-lo. (ASSIS, 1904, p.11).

A sensação de que uma tragédia poderia efetivamente acontecer já havia sido sugerida desde as primeiras linhas do conto, na referência à peça Hamlet, de Shakespeare. Curiosamente, Camilo intui sobre o que poderia lhe acontecer, contrariando a informação anterior de que não possuía "nem 
experiência, nem intuição". (ASSIS, 1904, p.4). As palavras de Vilela repassavam-lhe continuamente no pensamento, como se vaticinassem o seu destino.

O suspense construído, com a repetição dos termos do bilhete, prepara o leitor para o instante catártico, levando a narrativa num contínuo crescente, rumo ao clímax do enredo.

Sem poder fugir à situação, Camilo pega um tílburi para ir ter à casa de Vilela. No caminho, sente-se cada vez mais ansioso e amedrontado. Quando uma carroça atravanca a passagem, percebese parado na frente da residência da cartomante, o que lhe desperta uma curiosidade tentadora. Por várias vezes rejeita a ideia que lhe perpassa à mente, usando como argumento para tal repulsão, sua incredulidade.

É curioso notar que poucas são as informações sobre essa rua e a casa da cartomante. Porém, será neste percurso público que vai do Largo da Carioca até o Botafogo, que a sorte de Camilo será definida. O incidente com a carroça o colocava estrategicamente na frente de um espaço simbólico, que, mesmo sendo por ele refutado, exercia sobre o seu espírito uma influência significativa. Teria sido o destino que o levava ali, naquele exato instante? Sua comoção não parava de intensificar-se. $\mathrm{O}$ medo que invadia a alma de Camilo e perturbava profundamente o seu ser, podia ser percebido e vivenciado pelo leitor, por meio da construção de uma atmosfera de suspense, criada na espacialidade compositiva do texto. Vejamos um exemplo transcrito com marcações nas pausas das quais faz uso Machado de Assis:

Camilo fechava os olhos,/ pensava em outras cousas:/ mas a voz do marido sussurrava-lhe a orelhas as palavras da carta:/ "Vem,/ já,/ já..."/ E ele via as contorções do drama/ e tremia/. A casa olhava para ele/. As pernas queriam descer/ e entrar/. Camilo achou-se diante de um longo véu opaco.../ pensou rapidamente no inexplicável de tantas cousas/. A voz da mãe repetia-lhe uma porção de casos extraordinários/: e a mesma frase do príncipe de Dinamarca reboava-lhe dentro/: "Há mais cousas no céu e na terra do que sonha a filosofia..."/ Que perdia ele, se... /? (ASSIS, 1904, p.13).

As frases curtas marcadas ou pelas pausas, ou pelos pontos finais, criam um ritmo novo no texto, acentuando a sobreposição dos pensamentos de Camilo e, tal qual um metrônomo, marcam o compasso de sua comoção crescente. O uso da conjuntiva "e" no início de algumas orações, quebra completamente a pausa anterior e justapõe as frases umas às outras, como se a mente da personagem fosse tomada por lembranças e reflexões. A atmosfera tensa que permeia estas linhas constitui um espaço não descrito, mas inscrito no texto. Vale ressaltar aqui, também, a personificação do espaço em "A casa olhava para ele", como se Camilo tivesse sido levado até a residência da cartomante pela fortuna, e diante da sua relutância, a casa o convocasse adentrá-la. A personagem procura costurar sentidos para o inexplicável: o destino.

Uma nova referência à peça Hamlet é feita, porém, desta vez, a alusão parte de Camilo e, de certo modo, a frase proferida pelo "príncipe da Dinamarca" o ajuda a tomar uma resolução:

Deu por si na calçada, ao pé da porta: disse ao cocheiro que esperasse, e rápido enfiou pelo corredor, e subiu a escada. A luz era pouca, os degraus comidos dos pés, o corrimão pegajoso; mas ele não viu nem sentiu nada. Trepou e bateu. Não aparecendo ninguém, teve ideia de descer; mas era tarde, a curiosidade fustigava-lhe o sangue, as fontes latejavam-lhe; ele tornou a bater uma, duas, três pancadas. Veio uma mulher; era a cartomante. Camilo disse que ia consultá-la, ela fê-lo entrar. Dali subiram ao sótão, por uma escada ainda pior que a primeira e mais escura. Em cima, havia uma salinha, mal alumiada por uma janela, que dava para o telhado dos fundos. Velhos trastes, paredes sombrias, um ar de pobreza, que antes aumentava do que destruía o prestígio.

A cartomante fê-lo sentar diante da mesa, e sentou-se do lado oposto, com as costas para a janela, de maneira que a pouca luz de fora batia em cheio no rosto de Camilo. (ASSIS, 1904, p.15).

Esta passagem é muito representativa por sua composição cênica. As frases são curtas e diretas. As descrições são secas, mínimas, mas eficazes. A construção imagética do cenário é simples e por esta razão é quase imediata. Os passos de Camilo são enumerados e sua apreensão espiritual firma-se na 
descrição do ambiente: um corredor, uma escada, pouca luz, degraus gastos, uma porta. Vem a espera impaciente, a cartomante, uma nova escada mais estreita, um sótão mal iluminado, uma pequena sala, uma única janela e alguns trastes velhos espalhados. Os elementos compositivos da cena são poucos e apresentados objetivamente. Não há minúcias de detalhes. Não sabemos nada sobre a fachada da residência, de que material eram feitos os degraus da escada ou que trastes eram aqueles. Todavia, a ausência dessas informações não cria lacunas semânticas, pois a singularidade da escrita abriga a suficiência, exatamente como em um texto de teatro. Machado de Assis apropria-se desses recursos cênicos, transporta-os para sua narrativa e, partindo deste mesmo princípio de teatralidade, estrutura os espaços. Assim, como no texto dramático em que a apreensão do cenário da ação acontecia pela denominação de certos ambientes (jardim do palácio, salão de baile, aposentos do rei, etc.) e de alguns outros poucos elementos marcadores de cena, o espaço no conto forma-se sobre esta mesma base compositiva. Os poucos elementos propiciam a criação de um imaginário de mistério, enfatizando o suspense gerado pelo bilhete.

Na sequência da narrativa, a cartomante restitui a paz de espírito de Camilo por meio das previsões otimistas. É interessante notar como a percepção espacial do rapaz muda com essas revelações apaziguadoras:

A cartomante tinha já guardado a nota na algibeira, e descia com ele, falando, com um leve sotaque. Camilo despediu-se dela embaixo, e desceu a escada que levava à rua, enquanto a cartomante, alegre com a paga, tornava acima, cantarolando uma barcarola. Camilo achou o tílburi esperando; a rua estava livre. Entrou e sentiu o trote largo.

Tudo lhe parecia agora melhor, as outras cousas traziam outro aspecto, o céu estava límpido e as caras joviais. Chegou a rir dos seus receios, que chamou pueris; recordou os termos da carta de Vilela e reconheceu que eram íntimos e familiares. Onde é que ele lhe descobrira a ameaça? Advertiu também que eram urgentes, e que fizera mal em demorar-se tanto; podia ser algum negócio grave e gravíssimo. (ASSIS, 1904, p.17).

A rua, antes atravancada pela carroça, agora se encontrava livre, seus sentimentos também estavam atravancados por preocupações, mas foram libertos com as palavras da cartomante; o trote largo do cavalo que o angustiava, pois precipitava seu encontro Vilela, era percebido com tranquilidade; o céu apresentava outro aspecto, estava límpido, como a clareza e a certeza que sentia de que todas as suas aflições foram excessos de sua imaginação; as caras eram joviais e não mais curiosas... ou seja, o olhar de Camilo sobre o espaço urbano mudara. O que antes parecia assustador e aumentava a sua angústia, agora era claro e vivo. Não havia mais motivos para preocupar-se. A cartomante lhe garantira.

Apenas nós, leitores, sabemos o quanto essa falsa sensação de segurança e incapacidade intuitiva anunciada será fatal a Camilo:

Daí a pouco chegou à casa de Vilela. Apeou-se, empurrou a porta de ferro do jardim e entrou. A casa estava silenciosa. Subiu os seis degraus de pedra, e mal teve tempo de bater, a porta abriu-se, e apareceu-lhe Vilela.

- Desculpa, não pude vir mais cedo; que há?

Vilela não lhe respondeu; tinha as feições decompostas; fez-lhe sinal, e foram para uma saleta interior. Entrando, Camilo não pôde sufocar um grito de terror: - ao fundo sobre o canapé, estava Rita morta e ensanguentada. Vilela pegou-o pela gola, e, com dois tiros de revólver, estirou-o morto no chão. (ASSIS, 1904, p.19).

No final do conto a ação precipita-se rapidamente. As últimas ações de Camilo são descritas e marcadas verbalmente: chegou, apeou, empurrou, entrou, subiu, gritou... Há alguns indicativos do que poderia acontecer, como a casa silenciosa, o fato de Vilela vir abrir prontamente a porta, como se já o esperasse largamente, com as feições decompostas. O término abrupto da narrativa, a crueza da descrição e da resolução da vingança cometida é de grande composição dramática e quase se torna possível imaginarmos o pano caindo e fechando não apenas a cena, mas marcando o final do ato e da peça. 
Em "O diplomático" reiteram-se alguns elementos compositivos de "A cartomante", como a exploração do diálogo entre o narrador e os leitores, a linguagem sintética e precisa. Entretanto, neste conto é singular e explícita a apropriação do espaço público pelo espaço íntimo, doméstico. Vejamos como isso acontece:

Estamos na noite de São João de 1854, e a casa é na rua das Mangueiras. Chama-se João o dono da casa, João Viegas, e tem uma filha, Joaninha. Usa-se todos os anos a mesma reunião de parentes e amigos, arde uma fogueira no quintal, assam-se as batatas do costume, e tiram-se sortes. Também há ceia, às vezes dança, e algum jogo de prendas, tudo familiar. (ASSIS, 1904, p.169).

A tradicional festa junina, em homenagem a São João, não acontecia nas ruas, largos ou praças de igrejas como em outras cidades brasileiras. A festa popular "privatizava-se" já que acontecia dentro das casas de família. Fora o espaço, outros costumes característicos mantinham-se como a fogueira, a comida, a dança e a previsão das sortes. A casa de Viegas, localizada na rua das Mangueiras (atual Visconde de Maranguape), ficava próxima aos Arcos da Lapa.

No festejo, Rangel, protagonista da história e cuja alcunha é o diplomático, por sua educação e polidez, pretende entregar uma carta para Joaninha ${ }^{2}$, jovem filha de João Viegas, em cujas linhas procura declarar o seu amor e as suas intenções. Mas Rangel é homem sem brio, sem ímpeto. Posterga para outros momentos todas as oportunidades que aparecem. Esta ausência de iniciativa assolava apenas sua vida prática. Em seus sonhos e devaneios era "impetuoso, ardente, capaz de arrebatar de um lance a palma da fortuna". (ASSIS, 1904, p.171).

Antes de decidir-se por Joaninha, Rangel frequentou outros espaços onde esperava encontrar uma "noiva superior". Todos, sem exceção, espaços reclusos, burgueses, onde apenas certas camadas da sociedade podiam transitar:

Chegou a frequentar os bailes de um advogado célebre e rico, para quem copiava papéis, e que o protegia muito. Tinha nos bailes a mesma posição subalterna do escritório; passava a noite vagando pelos corredores, espiando o salão, vendo passar as senhoras, devorando com os olhos uma multidão de espáduas magníficas e talhes graciosos. Invejava os homens, e copiava-os. Saía dali excitado e resoluto. Em falta de bailes, ia às festas de igreja, onde poderia ver algumas das primeiras moças da cidade. Também era certo no saguão do paço imperial, em dia de cortejo, para ver entrar as grandes damas e as pessoas da corte, ministros, generais, diplomatas, desembargadores, e conhecia tudo e todos, pessoas e carruagens. (ASSIS, 1904, p.172).

A única referência no texto a um espaço mais popular é quando o narrador explica que Rangel conhecia Joaninha desde que ela era criança: “Andara com ela ao colo no Passeio Público" inclusive. A personalidade romântica do protagonista impregna a ficção e a enunciação do narrador, que se torna repleta de metáforas e comparações. Há certa ironia neste procedimento, o que pode sugerir uma crítica velada ao romantismo: Joaninha é comparada a uma espiga baixinha de milho, passível de ser apanhada por Rangel, pois "bastava esticar o braço com algum esforço, para arrancá-la do pé". (ASSIS, 1904, p.173). Esta comparação não é muito romântica, ao contrário, aborda o amor de forma premeditada e calculista, assente em um dito popular.

Como em "A cartomante", o narrador, em determinado momento recua a narrativa para explicar situações anteriores e, depois, volta no exato instante em que a havia suspendido:

Agora mesmo traz ele a primeira carta de amor, disposto a entregá-la. Já teve duas ou três ocasiões boas, mas vai sempre espaçando; a noite é tão comprida! Entretanto, continua a ler as sortes, com a solenidade de um áugure. (ASSIS, 1904, p.173).

2 A personagem possui alguns traços semelhantes à jovem romântica de Viagens na minha terra (1846), de Almeida Garrett. Além do nome, ambas possuem como grande atrativo o par de olhos. A Joaninha, de Garrett, os tinha verdes. Em Machado, são "lindos e sossegados, virgens de toda a conversação masculina” (ASSIS, 1904, p. 172). 
Numa espécie de marcação de cena, o narrador retoma o protagonista no mesmo espaço e no mesmo instante em que o havia deixado momentos antes de iniciar sua digressão, recuperando assim, toda a unidade narrativa interrompida. É interessante observar que a imparcialidade do narrador em terceira pessoa, em alguns momentos, torna-se questionável. Sua ironia é explícita, observável no modo como enuncia as ações da personagem, ridicularizando-as por diversas vezes.

Quando as leituras das sortes acabam, todos os presentes dispersam. Joaninha, seguida por Rangel, vai à janela:

Defronte, numa casa grande, havia um baile, e dançava-se. Ela olhava, ele olhou também. Pelas janelas viam passar os pares, cadenciados, as senhoras com as suas sedas e rendas, os cavalheiros finos e elegantes, alguns condecorados. De quando em quando, uma faísca de diamantes, rápida, fugitiva, no giro da dança. Pares que conversavam, dragonas que reluziam, bustos de homem inclinados, gestos de leques, tudo isso em pedaços, através das janelas, que não podiam mostrar todo o salão, mas adivinhava-se o resto. (ASSIS, 1904, p.174).

Nesta passagem percebe-se outro costume bem característico dos salões do Rio de Janeiro oitocentista: um baile. A rua, de apropriação pública em tantas cidades europeias, torna-se efetivamente mero limite entre festas e espaços privados. Em cada residência acontecia um tipo de reunião, para determinada sorte de gente. A sociedade estratifica-se assim, em espaços afins e segregados.

A chegada de Queirós na festa de S. João abalou os planos de Rangel. O moço era, na prática, idêntico ao que ele, Rangel, era apenas em seus sonhos: desembaraçado, espontâneo, distinto, encantador, cosmopolita. A partir deste instante, o narrador expressa bem o ciúme do protagonista com o aparecimento do concorrente. Sim, um concorrente, pois Joaninha mostrava-se notadamente atraída pelo rapaz:

Teso na cadeira, o Rangel estava atônito. Donde vinha esse furacão? E o furacão ia soprando, levando os chapéus dos homens, e despenteando as moças, que riam de contentes: Queirós daqui, Queirós dali, Queirós de todos os lados. Rangel passou da estupefação à mortificação. Era o cetro que lhe caía das mãos. Não olhava para o outro, não se ria do que ele dizia, e respondia-lhe seco. Interiormente, mordia-se e mandava-o ao diabo, chamava-o bobo alegre, que fazia rir e agradava, porque nas noites de festa tudo é festa. Mas, repetindo essas e piores coisas, não chegava a reaver a liberdade de espírito. Padecia deveras, no mais íntimo do amor-próprio; e o pior é que o outro percebeu toda essa agitação, e o péssimo é que ele percebeu que era percebido. (ASSIS, 1904, p.181).

Esta cena possui um forte humorismo. O uso do discurso indireto livre garante fluidez ao trecho e repete com grande teatralidade as falas despeitadas de Rangel. O desfecho do conto torna-se previsível: "a espiga de milho baixinha" seria apanhada por outro - se é que é permitida esta apropriação da expressão usada pelo narrador. Este, porém, muito próximo da linguagem do provérbio dramático, encerra a narrativa de outra forma:

O pobre-diabo, feito de devaneio, indolência e afetação, era, em substância, tão desgraçado como Otelo, e teve um desfecho mais cruel.

Otelo mata Desdêmona; o nosso namorado, em quem ninguém pressentira nunca a paixão encoberta, serviu de testemunha ao Queirós, quando este se casou com Joaninha, seis meses depois. (ASSIS, 1904, p.185-186).

A referência à peça Otelo cria uma intertextualidade e um diálogo entre as personalidades dos protagonistas, ao indicar que Rangel e o mouro de Veneza são marcados pela tragicidade. Entretanto, salienta o narrador, de modo satírico, que seria menos trágico matar a esposa, tal como o fez Otelo, do que servir de testemunha ao enlace matrimonial da mulher desejada com outro homem, como ocorreu com Rangel. Porém, permanece a pergunta: qual seria o provérbio oculto neste conto? Quem sabe "não deixes para amanhã o que podes fazer hoje...".

Para concluir as análises, o conto "Mariana" apresenta uma estrutura bem diferente dos outros dois, 
pois aparece dividido em três capítulos. Evidencia-se, assim, a fragmentação das unidades narrativas em cenas.

No primeiro capítulo é apresentado Evaristo. Ficamos sabendo que chegara ao Rio de Janeiro poucos dias antes, no início de 1890, após uma ausência de dezoito anos. O narrador explica que Evaristo estendera sua estada em Paris, pois "o viajante põe e Paris dispõe", trocadilho adaptado do provérbio "o homem põe e Deus dispõe". A personagem após adentrar "aquele mundo" esqueceu-se das coisas do Brasil, construção esta que reforça as diferenças culturais existentes entre a capital francesa e a capital dos trópicos. Sua volta fora motivada por um súbito interesse em colher informações sobre a revolução acontecida no Rio em novembro de 1889, referência indireta à Proclamação da República. Uma vez na cidade, Evaristo resolve visitar Mariana, um antigo amor de maturidade. Encerra-se esta cena, para iniciar outra, juntamente com o segundo capítulo:

Dias depois apeava-se ele de um tílburi à porta de Mariana, e dava um cartão ao criado, que lhe abriu a sala.

Enquanto esperava circulou os olhos e ficou impressionado. Os móveis eram os mesmos de dezoito anos antes. A memória, incapaz de os recompor na ausência, reconheceu-os a todos, assim como a disposição deles, que não mudara. Tinham o aspecto vetusto. As próprias flores artificiais de uma grande jarra, que estava sobre um aparador, haviam desbotado com o tempo. Tudo ossos dispersos, que a imaginação podia enfaixar para restaurar uma figura a que só faltasse a alma.

Mas não faltava a alma. Pendente da parede, por cima do canapé, estava o retrato de Mariana. (ASSIS, 1904, p.194).

Na sala a disposição dos móveis permanecia a mesma. Nada havia mudado, apenas envelhecido, descolorido com o passar dos anos. O quadro "era o único alento vivo da sala; mas só ele bastava a dar à decrepitude ambiente a fugidia mocidade”. (ASSIS, 1904, p.195). Evaristo sentiu-se voltar no tempo, pois a lembrança que tinha de Mariana, não distava muito em idade da imagem do retrato. Nesse instante, como nos outros dois contos, a narrativa é interrompida, porém não por uma digressão explicativa, mas por um devaneio de Evaristo que constitui a terceira cena do conto. Nele, a figura de Mariana sai da moldura do quadro e vai ter com ele à cadeira, onde conversam e repassam cenas antigas do relacionamento dos dois. A passagem, marcada por diálogos, se encerra com a fala de um criado, ruptura temporal que devolve o protagonista à realidade e dispersa a situação onírica na qual mergulhara.

Inicia-se o terceiro capítulo. Duas cenas marcam esta última fragmentação narrativa. A primeira apresenta o marido de Mariana em um quarto, bastante enfermo:

Xavier estava no gabinete próximo, estirado em um canapé, com a mulher ao lado e algumas visitas.
Evaristo penetrou ali cheio de comoção. A luz era pouca, o silêncio grande; Mariana tinha presa
uma das mãos do enfermo, a observá-lo, a temer a morte ou uma crise. Mal pôde levantar os olhos
para Evaristo e estender-lhe a mão; voltou a fitar o marido, em cujo rosto havia a marca do longo
padecimento, e cujo respirar parecia o prelúdio da grande ópera infinita. Evaristo, que apenas vira
o rosto de Mariana, retirou-se a um canto, sem ousar mirar-lhe a figura, nem acompanhar-lhe os
movimentos. Chegou o médico, examinou o enfermo, recomendou as prescrições dadas, e retirou-se
para voltar de noite. Mariana foi com ele até à porta, interrogando baixo e procurando-lhe no rosto
a verdade que a boca não queria dizer. Foi então que Evaristo a viu bem; a dor parecia alquebrá-la
mais que os anos. Conheceu-lhe o jeito particular do corpo. Não descia da tela, como a outra, mas
do tempo. Antes que ela tornasse ao leito do marido, Evaristo entendeu retirar-se também, e foi até
a porta. (ASSIS, 1904, p. 201-202).

A cena possuiu uma forte dinâmica teatral e, como em um texto dramático, apresenta muitos elementos cênicos, necessários à sua efetiva encenação: a indicação da movimentação das personagens e das suas expressões corporais é a grande responsável pela teatralidade obtida neste trecho. Somada às outras poucas informações da estruturação do cenário, como luz e som, será a movimentação das personagens em cena a formadora da ambientação. A primeira oração compõe efetivamente a cena. Apresenta o foco principal, Xavier, estirado em seu leito em um gabinete "próximo" à sala onde 
Evaristo se encontrava. As poucas pessoas que participam do quadro estão dispostas ao redor do doente, entre elas Mariana. Depois, uma indicação da movimentação do protagonista que "penetrou" aquele espaço pouco iluminado e silencioso. Percebe que Mariana retém, nas suas, uma das mãos do marido. Mal se olham e Evaristo "retira-se" para um canto. Uma nova personagem surge: o médico. Sua entrada e suas ações são indicadas verbalmente: "chegou", "examinou", "recomendou" e "retirou-se". Depois, novas movimentações: Mariana "vai" até a porta, "conversa" baixo com o médico enquanto é "observada" por Evaristo do gabinete que logo "se retira" do recinto e, também, "dirige-se" até a porta.

A última cena a ser comentada, a morte de Xavier, é melodramática em sua composição. Algumas expressões dispostas regularmente no texto corroboram a assertiva, pois seus significados semânticos elevam o descomedimento das ações representadas. Na transcrição da passagem, tais expressões foram colocadas entre aspas:

Xavier durou ainda uma semana. Indo fazer-lhe segunda visita, Evaristo "assistiu à morte" do enfermo, e não pôde furtar-se à "comoção natural" do momento, do lugar e das circunstâncias. Mariana, "desgrenhada" ao pé do leito, tinha os "olhos mortos de vigília e de lágrimas". Quando Xavier, depois de "longa agonia", expirou, mal se ouviu o choro de alguns parentes e amigos; "um grito agudíssimo" de Mariana chamou a atenção de todos; depois o "desmaio e a queda da viúva". Durou alguns minutos a "perda dos sentidos"; tornada a si, Mariana "correu ao cadáver, abraçou-se a ele, soluçando desesperadamente", dizendo-lhe os nomes mais queridos e ternos. Tinham esquecido de fechar os olhos ao cadáver; daí um "lance pavoroso e melancólico", porque ela, depois de os beijar muito, foi "tomada de alucinação e bradou" que ele ainda vivia, que estava salvo; e, por mais que quisessem "arrancá-la" dali, não "cedia, empurrava" a todos, "clamava" que queriam tirar-lhe o marido. "Nova crise a prostrou"; foi levada "às carreiras" para outro quarto. (ASSIS, 1904, p.206).

Diferentemente da cena anterior, onde as indicações cênicas atribuíam o caráter teatral ao texto, nesta passagem, o efeito melodramático é suficiente para a sua efetivação. A escrita é trabalhada de forma que o leitor possa sentir, e quase presenciar imaginariamente, a comoção do instante. A morte de Xavier, o descontrole de Mariana, sua perda de razão. É interessante observar também que a referência à protagonista, depois do falecimento do marido, não se serve mais do seu nome, "Mariana", mas, sim, de seu estado, "viúva". Esta transformação abrupta opera uma ruptura significativa que intensifica e racionaliza a morte.

A teatralidade também é obtida por meio da pontuação. O uso seguido do ponto e vírgula garante a continuidade das ações, provocando expectativa e ansiedade nas pausas criadas. Estas sensações são mantidas em todo o trecho pela surpresa gerada no desenrolar de cada acontecimento.

No fim do conto, Evaristo frustra-se com a indiferença de Mariana e, desiludido, regressa para Paris, a tempo de, metaforicamente, testemunhar o insucesso da peça de seu amigo.

\section{Considerações finais}

Buscou-se, ao longo do artigo, apresentar algumas das relações guardadas entre Machado de Assis, o teatro, e a cidade do Rio de janeiro. Observou-se que em muitos momentos o escritor transpôs, para seus contos, a estrutura da escrita dramática e cingiu sua ficção de teatralidade. A convivência com esta arte lhe proporcionou não apenas uma sólida formação cultural, mas, sobretudo, um extraordinário domínio da forma dramática. Como foi demonstrado, são significativos certos modos teatrais de armar as cenas, de movimentar as personagens, de indicar os cenários das ações ficcionais e de organizar os diálogos. O texto, não raramente, aparece fragmentado em unidades narrativas, dividido em episódios, pequenos quadros compositivos. Os espaços, por sua vez, estão impregnados de indicações cênicas, responsáveis pela constituição das ambientações.

Observou-se também que a cidade do Rio de Janeiro permeia os contos enquanto atmosfera urbana 
e cosmopolita, estratificando socialmente as personagens. Não há vivência dos espaços públicos, pois esta não era uma característica da capital oitocentista. As ruas pertenciam aos escravos, aos vendedores ambulantes, não às classes burguesas e aristocráticas, a não ser em lugares muito específicos. Assim, os espaços públicos, bem como todas as ações passíveis de serem nele desempenhadas, privatizam-se. As festas, bailes, brincadeiras e jogos transferem-se para outra esfera: a intimidade das residências.

Para encerrar, as linhas finais de "Mariana", são interessantes: "Cousas de teatro, disse Evaristo ao autor, para consolá-lo. Há peças que caem. Há outras que ficam no repertório.” (ASSIS, 1904, p.207).

A obra machadiana certamente nunca cairá do repertório.

\section{Referências}

ASSIS, Machado de. “A cartomante”. In: ASSIS, Machado de. Várias Histórias. Rio de Janeiro: H. Garnier; Paris: H. Garnier, 1904, pp.3-19.

ASSIS, Machado de. “O diplomático”. In: ASSIS, Machado de. Várias Histórias. Rio de Janeiro: H. Garnier; Paris: H. Garnier, 1904, pp.169-187.

ASSIS, Machado de. "Mariana". In: ASSIS, Machado de. Várias Histórias. Rio de Janeiro: H. Garnier; Paris: H. Garnier, 1904, pp.191-207.

ASSIS, Machado de. História de quinze dias. São Paulo: Globo, 1997 (a). (Obras completas de Machado de Assis)

ASSIS, Machado de. Notas semanais. São Paulo: Globo, 1997 (b). (Obras completas de Machado de Assis)

MACEDO, Joaquim Manuel de. Um passeio pela cidade do Rio de Janeiro. Rio de Janeiro; Belo Horizonte: Garnier, 1991. (Coleção Imagens do Brasil, vol.1)

PINHEIRO, Eloísa Petti. Europa, França e Bahia: difusão e adaptação de modelos urbanos (Paris, Rio e Salvador). Salvador: EDUFBA, 2002. 